\title{
Children Involvement in Rice Cultivation: Assessment of Their Role and Impact in Sokoto State, Nigeria
}

\author{
Ango Adamu Kamba ${ }^{1}$, Mamman Muntaka ${ }^{2}$, Muhammad Ahmad ${ }^{2}$, Ndubueze Precious ${ }^{1}$ \\ ${ }^{1}$ Department of Agricultural Extension and Rural Development, Faculty of Agriculture, Usmanu Danfodiyo University, Sokoto, Nigeria \\ ${ }^{2}$ Department of Agricultural Extension and Rural Development, Faculty of Agriculture and Engineering, Federal University, Dutsin-Ma, \\ Nigeria
}

\section{Email address: \\ aakamba2@gmail.com (A. A. Kamba), ango.adamu@udusok.edu.org.ng (A. A. Kamba)}

\section{To cite this article:}

Ango Adamu Kamba, Mamman Muntaka, Muhammad Ahmad, Ndubueze Precious. Children Involvement in Rice Cultivation: Assessment of Their Role and Impact in Sokoto State, Nigeria. International Journal of Applied Agricultural Sciences. Vol. 7, No. 2, 2021 , pp. 89-97. doi: $10.11648 /$ j.ijaas.20210702.13

Received: October 22, 2020; Accepted: February 7, 2021; Published: March 22, 2021

\begin{abstract}
This study assessed the role of children in rice cultivation in Sokoto state. Two Local Government areas were purposely selected from the two Agricultural Development Programme zones of the state. Data were obtained through the administration of structured questionnaire and analyzed using descriptive and inferential statistics. Findings of the study revealed that majority $(74.99 \%)$ of the children actively participated in rice cultivation and were between the ages of 9-16 years with mean age of about 12 year and 8 months, 55\% of them were males with majority enrolled in to Qur'anic schools only. Majority $(84.16 \%)$ of the children spent 4-7 hours working per day with an average of 4.55 days working per week with a mean income of 18,175 year. The common rice cultivation activities engaged by the children included transplanting, weeding, fertilizer application, birds scaring, harvesting and processing. All the children were motivated in to rice production business by provision of incentives (food, clothing and money). The study concludes that majority of the children were under age and engaged in to rice cultivation purposely for some life necessities and recommends that government should come up with better incentives that could attract the attention of the children towards pursuance of education and acquirance of other technical skills.
\end{abstract}

Keywords: Assessment, Role, Children, Farm Labour, Rice Cultivation

\section{Background of the Study}

Agriculture, since time immemorial has been found to sustain human beings in their lively dealings. Ever since the first man learnt to till the soil and raise animals, agriculture has consistently being the source of food, feed and shelter for himself and animals in addition to provision of clothing, employment and raw materials for industries [1]. Agriculture is an important sector of Nigeria's economy in spite of the decline it has incurred due to the discovery of oil in the 1970s and the country is endowed with land and water resources capable of supporting any sort of agricultural practice [2]. FAO further indicated that presently, Nigeria has about 79 million hectares of arable land of which only about 33 millions are being cultivated and with abundance underground and surface water resources.

The availability of the natural resources in Nigeria was the reason why majority of its inhabitants opted for agricultural practices as the main source of livelihood and employer of more than $60 \%$ of the populace. Many assorted crop varieties and animals are raised in Nigeria and rice was considered as one of the crops produced and is being considered as the staple food for majority of the citizenry.

Rice crop immensely contributes to internal and external African sub-regional trade as well as food security for the nation. It's an important food crop that provides food security as well as an essential cash crop for both small and largescale producers who mostly sell about 80 percent of their total production and consume only 20 per cent [3]. In the year 2015, the Nigeria Federal Ministry of Agriculture and Rural Development reported that the rice sub sector of the economy generated about4, 706 billions to the Nigerian economy. Over the last three years of rice transformation programme, rice had added3, 206 billions to the nation's 
economy [4]. The Ministry further reported that from 20112015 , rice subsector in Nigeria has attracted over $\$ 2$ billion over private sector investments. It was further reported that the Federal Government of Nigeria has saved about $\$ 800$ million by encouraging local production of rice in the country [5].

The agricultural sector was found to be the main employer of children in the world, accounting for 60 percent of an estimated 215 million child labourers [6]. Children are said to constitute a large component of Nigeria's population and contributed a lot to the development of the nation and in particular their local communities [7]. Their participation or involvement in agricultural production is a way of increasing their skills, knowledge, confidence and self-reliance and opportunity to collaborate and engaged them in sustainable development [8]. Although some argued that the involvement of children in agricultural production was due to inability of majority of farmers to afford employing older, physically stronger and skilled workers thereby leading to increased demand for child workers [9] While others argued that the demand for children's work on the family farm is kept in check by social and cultural values regarding how best to prepare children's future [10].

However, one weakness in this line of arguments is that it offers little explanation of why some farmers employ children from the extended family or outside the network of kin [11]. Over 129 million girls and boys aged 5 to 17 years old work in crop and livestock production, fisheries, aquaculture and forestry helping in supply of some of the food and drink consumed and the fibbers and raw materials used to make other products. More concentration in engaging children in farm and industrial work force (Child labour), has attracted a great concern in many parts of the world including Nigeria and it appears to be particularly widespread in the informal, small and medium-scale sectors $[12,13]$.

This therefore, calls for an attempt to distinguish between child labour and child work/participation. Accordingly, participation in some agricultural activities is not always a child labour [14]. Age- appropriate tasks that are of lower risk and do not interfere with a child's schooling and leisure time can be a normal part of growing up in a rural environment especially in the context of family farming, small-scale fisheries and livestock husbandry. As further reported some participation of children in non-hazardous activities can be positive as it contributes to the inter-generational transfer of technical and social skills and children's food security [14]. Therefore, it is important to distinguish between light duties that do no harm to the child and child labour, and such work should not interfere with compulsory schooling and damages health and personal development of the child.

\subsection{Statement of the Problem}

Child work/participation is considered to have essential socialization functions while child labour tends to take place outside the family and sometimes could be exploitative [15]. Child labour is considered as a work performed by children under 18 years of age which is exploitative, hazardous or inappropriate for their age, as well as detrimental to their schooling, social, mental, spiritual and moral development. Child labour shrinks the opportunities of children schooling and also enslaves and separate them from their families. In most cases, this practice is often in violation of international laws and national legislation on children rights [16].

During the rice planting season in the study area, most of the activities of rice production are carried out by children who assist their parents in the early farming stages as well as during weeding. Young girls serve as labourers in transplanting of rice seedlings, weeding, and birds scaring (scarecrows in the rice field) and were found to be more efficient than most adult labourers although they receive fewer wages when compared to the adult.

However, rice cropping system in the study area is beset with problems associated with low-labour output, low yield; relatively high production costs, poor producer price and marketing system and these could be the reason behind children involvement in the rice production processes. Based on the above premise, rural children in the study area contribute significantly in rice production even though their contributions are usually undervalued, their economic potentials not fully utilized, they are in most cases over exploited (child labour) and which deprives them of their childhood potentials and with no recognized record on their contribution to food security in the study area and beyond.

It's based on the aforementioned dearth in knowledge of the role children play in rice production that this study provides answer to stated objectives. They include: (a) describe the demographic characteristics of children engaged in rice production in the study area (b) determine the level of their involvement and benefits derived from rice production (c) ascertain the perceived effects of children participation in rice production and (d) determine whether the involvement of children leads to increase in rice yield in the study area.

\subsection{Research Hypothesis}

$\mathrm{Ho}_{1}$ : There is no significant relationship between the involvement of children in rice production and rice yield obtained in the study area.

\section{Research Methodologies}

\subsection{Study Area}

This study was conducted in Northern Zone of Sokoto State Agricultural Development Project. The zone is located on latitude $13^{\circ} 43^{\prime} 79^{\prime} \mathrm{N}$ and Longitude $5^{\circ} 67^{\prime} 87^{\prime} \mathrm{E}$ with a land area of $1,704 \mathrm{~km}^{2}$. The area falls within the Sudan Savannah agro-ecological zone of Nigeria with a short and erratic period of rainfall (May to September) and long dry season (October to May) with a mean annual rainfall of about 645 $\mathrm{mm}$ per annum [17]. Similar to other extreme northern parts of the country, rainfall in the area is erratic and unpredictable with irregular onsets and cessations which adversely affect duration of cropping seasons. The wet season lasts from June to September with annual rainfall range of $300 \mathrm{~mm}$ to $800 \mathrm{~mm}$ 
[17]. Crops mainly produced in the area include millet, guinea corn, maize, rice, potatoes, cassava, groundnut, cowpea, wheat, cotton and vegetable crops while some inhabitants engaged in fishing and raising of variety of animals.

\subsection{Sampling Technique and Sample Size}

The population of this study constitutes all the children engaged in rice cultivation in the study area. Sokoto State Agricultural Development Project (ADP) has been divided into two Agricultural zones; namely: Southern and Northern zones. Northern Zone of Sokoto state ADP was purposively selected for the study due to high rate of rice cultivation in the zone. Multi-stage sampling technique was used to arrive at the sample size of 120 children. In the first stage, two Local Government Areas (Goronyo and Wurno Local Government Areas) were also purposively selected due to high level of children engagement in the rice cultivation. In the second stage, one district each was randomly selected from each of the selected Local Government Areas. In the third stage, three villages each were selected from the districts. Finally, from each of the selected villages, certain numbers of the children, depending on the population of the children in rice cultivation were randomly selected (See Table 1), making the sample size of the study to constitute one hundred and twenty (120) children.

Table 1. Sampling Procedure and Sample Size.

\begin{tabular}{|c|c|c|c|c|c|}
\hline $\begin{array}{l}\text { State ADP } \\
\text { Zones }\end{array}$ & $\begin{array}{l}\text { Zone } \\
\text { Selected }\end{array}$ & LGAs in the Selected zone & $\begin{array}{l}\text { Districts in the } \\
\text { LGA selected }\end{array}$ & $\begin{array}{l}\text { Villages in the } \\
\text { selected districts }\end{array}$ & $\begin{array}{l}\text { No. of Children } \\
\text { selected }\end{array}$ \\
\hline Southern Zone & $\begin{array}{l}\text { Northern } \\
\text { Zone }\end{array}$ & Goronyo, IsahRabah, S/Birni & Goronyo & $\begin{array}{l}\text { Takakume Rimawa } \\
\text { Keta }\end{array}$ & $\begin{array}{l}21 \\
24 \\
15\end{array}$ \\
\hline & & $\begin{array}{l}\text { Kware, Gwadabawa, Wurno, Binji } \\
\text { Silame, Gudu, Sokoto north, illela and Tangaza }\end{array}$ & Wurno & $\begin{array}{l}\text { Lugu Sabon Birni } \\
\text { Gidan Kamba }\end{array}$ & $\begin{array}{l}25 \\
12 \\
23\end{array}$ \\
\hline $\begin{array}{l}\text { Northern Zone } \\
\text { Total }\end{array}$ & & & & & 120 \\
\hline
\end{tabular}

Source: Field survey, 2018

\subsection{Methods of Data Collectionand Analysis}

The data for the study was obtained from both primary and secondary sources. The primary data was collected through the use of structured questionnairesand administered through interview schedule. While the secondary information was sourced from documented materials such as journals, books, books of proceedings, official records and internet source. In order to obtain primary data for this study, two sets of questionnaires were administered; one on the children engaged in rice cultivation and the other was administered on the parents and the employers of labour of children in the study area. To collect data on the perception of the children on their involvement in rice cultivation, five points Likert rating scale was used andwas rated based on Strongly agree (5points), Agree (4 points), Slightly agree (3 points), Disagree ( 2 points) and Strongly disagree (1 point) and viceversa depending on the nature of the attitudinal statement.

Data obtained was subjected to both descriptive (percentage, frequency counts, mean, standard deviation and ranking) and inferential (Multiple regression) statistical analysis. The ranking of the perceived responses of the children on their engagement in rice cultivation was based on higher mean response of the children.

\subsection{Measurement of Study Variables}

The study considers two sets of variables; dependent and independent variables. The dependent variable of the study is the perceived role of children in rice production while the independent variables of the study included children's demographic characteristics, children's level of involvement in rice production and the effects of their involvement in rice yield.

Age was measured based on chronological age (years); Educational attainment, based on Qur'anic education only $=1$, primary school education $=2$, and secondary school education=3; Household sizewas measured by the total number of people in the child's household; Rice production resources, was measured according to the rice production resources available to the children in the study area; level of involvement in rice production by the children was measured as highly involved $=1$, moderately involved $=2$ and not involved $=3$ and effects of involving children in rice production was measured based on privileges deprived, yield in rice by the parents/employers and benefits derived by the children.

\subsection{Model Specification}

\section{Regression Analysis}

$$
y=\beta_{\mathrm{o}}+\beta_{1} \mathrm{x}_{1}+\beta_{2} \mathrm{x}_{2}+\ldots \ldots \ldots \ldots \ldots+\beta_{\mathrm{n}} \mathrm{x}_{\mathrm{n}}+\mathrm{e}
$$

Where

$y=$ dependent variable (Role of children)

$x_{\mathrm{i}}=$ Demographic characteristics (age, sex, educational attainment, household size)

$x_{2}=$ Children level of involvement

$x_{3}=$ Rice production resources available to the children

$x_{4}=$ Consequences of using children in the fields

$x_{5}=$ Yields obtained as a result of children involvement 


\section{Results and Discussion}

\subsection{Socio-economic Characteristics}

Results in Table 2 show that $41.66 \%$ of the children were between the ages of $13-16$ years and $33.33 \%$ of them were between the ages of $9-12$ years. The mean age for the children engaged in rice production in the study area was 12.77 years, indicating that most of the children were under age and which has consequences on their quest for pursuance of education. This findings is in agreement with a study which reported that children with years ranging from 3, 4, 9, 13 and 14 years are engaged in cocoa, coffee, corn, tea, tobacco and rice production and some of them acting as scarecrows in the rice fields [18]. In contrast, another study reported that the recommended age for working children in developing and economically less developed countries is 14 years 19].

The findings in the Table further depict that more than half $(55.0 \%)$ of the children were males whereas $45 \%$ were females. This shows that male children dominates in the participation of rice cultivation even at lower age which could be attributed to the tradition and religious set up of the people in the study area. A child labour is much higher among boys than among the girls [19].

The Table further shows that majorities $(90 \%)$ of the children attained Qur'anic education only, $7.5 \%$ had primary school education and few $(2.5 \%)$ of them attained secondary school education. This finding goes in accordance with the norms and values of the people of the study area where low or no regards to western education is recognized, rather the children concentrate more on studying religious education and farming. This finding agrees with reports that children's social and cultural backgrounds play an important role in their participation in work and educational opportunities and that children engaged in farm works have no time for schooling.

As also indicated in Table 2, about $44.17 \%$ of the children lived within a household of $1-8$ people, $30.83 \%$ of them lives in the household of $9-16$ people and $17.5 \%$ of the children lives in a household of 17-25 family members [20]. The findings revealed a mean family size of 12 people indicating that most of the children were born and bred in a moderately large family size. This finding is in line with a report which stated that an average family size of 10 people per household is termed as moderate household size in a rural setting especially in northern part of Nigeria where polygamy is widely practiced [21]. Involvement of children into rice cultivation could be attributed to the household size where the parents due to lack of enough fund could not cater for their schooling rather, engage them in to either family labour or allow them to serve as labourers elsewhere, purposely to contribute in to family up-keeping. The incidence of poverty has cause children to work for their survival and many parents depend on their children even though they know that it's wrong to engage children in laborious activities that is detrimental to their mental health and schooling [13].

Table 2. Distribution of Children According to their Demographic Characteristics $(n=120)$

\begin{tabular}{|c|c|c|c|c|}
\hline VariableAge & Frequency & Percentage & Mean & Standard Deviation \\
\hline \multicolumn{5}{|l|}{ Age } \\
\hline 5 to 8 & 13 & 10.83 & \multirow{4}{*}{12.77} & \\
\hline 9 to 12 & 40 & 33.33 & & \\
\hline 13 to 16 & 50 & 41.66 & & 3.35 \\
\hline 17 and above & 17 & 14.16 & & \\
\hline \multicolumn{5}{|l|}{ Sex } \\
\hline Male & 66 & 55.0 & & \\
\hline Female & 54 & 45.0 & & \\
\hline \multicolumn{5}{|l|}{ Educational attainment } \\
\hline Qur'anic Education Only & 108 & 90 & & \\
\hline Primary Education & 9 & 7.5 & & \\
\hline Secondary Education & 3 & 2.5 & & \\
\hline \multicolumn{5}{|l|}{ Household size (people) } \\
\hline 1 to 8 & 53 & 44.17 & \multirow{4}{*}{ 12people } & \multirow{4}{*}{7.07} \\
\hline 9 to 16 & 37 & 30.83 & & \\
\hline 17 to 25 & 21 & 17.50 & & \\
\hline 26 and above & 9 & 7.5 & & \\
\hline \multicolumn{5}{|c|}{ Estimated annual income (N) } \\
\hline$<\mathrm{N} 11,000$ & 82 & 68.33 & \multirow{5}{*}{ N18,175 } & \multirow{5}{*}{2.89} \\
\hline$\$ 11,000-\$ 50,000$ & 16 & 13.33 & & \\
\hline $\mathrm{N} 51,000-\mathrm{N} 70,000$ & 14 & 11.67 & & \\
\hline$\$ 71,000-\$ 90,000$ & 5 & 4.17 & & \\
\hline N91,000 and above & 3 & 2.5 & & \\
\hline
\end{tabular}

Source: Field survey, 2018.

Results in Table 2 also reported that most $(68.33 \%)$ of the children earned less than $\$ 11,000$ annually, $13.33 \%$ of them earned between $\$ 11,000$ to $\$ 50,000$ /annum and few $(4.17 \%$ ) earned between $\$ 71,000-\$ 90,000$ /annum. The mean annual income of the children was $\$ 18,175$. This finding implies that the children got a meager amount of money when compared to their denial from active participating in the pursuance of education and other skills. Their engagement in to provision of 
labour in the rice fields could be due to the poverty status of their parents where the meager amount obtained by the children could be used for the up-keeping of the households. This finding disagree with the report that the richer the household the more vulnerable their children are to child labour syndrome [22].

\subsection{Involvement of Children in Rice Cultivation}

Children are known to be engaged in many rice cultivation activities, such activities include planting, transplanting, irrigation, weeding, fertilizer application, harvesting winnowing and scarecrows in the rice field through providing man power either on weekly or on daily basis and get paid in return either in cash or in kind. As shown in Table 3, all $(100 \%)$ the children were engaged in rice cultivation. This finding indicates that the high level of poverty among the households could be the reason behind engaging or given out children for hired labour in return of the proceeds that could be used to cater for the family. This finding agree with [13] reported that the incidence of poverty has cause children to work for their survival and many parents depend on their children even though they know that it's wrong. [23] Further reported the reasons behind child involvement in laborious activities and which included poverty, low parental income, being cheap source of labour, over population, unemployment of elders and parental illiteracy.

\subsubsection{Mode of Involving Children in Rice Production Activities}

The result in Table 3 reported that more than half (50.83\%) of the children were involved in transplanting, $24.16 \%$ were involved in weeding and $10 \%$ of the children were engaged in scarecrows in the rice field. This finding corroborates with that of [14] reported that child labour in farming may involve: preparation of land, transport and planting of seedlings, weeding, applying fertilizers and spraying pesticides, harvesting, and processing of collected crops.

This finding revealed that children participated actively in almost all the rice cultivation activities without any specification. This could be the reason why majority of the children spent considerable amount of their time working and actively participating in almost all the type of rice cultivation activities in the study area and which could be hazardous to their health. This finding is in line with [24] reported that stress, long hours of working, fast-faced work, isolation, intimidation-to name a few-can all cause injuries to the children that could not be quickly healed.

\subsubsection{Level Children Involvement in Rice Production}

Table 3 further reported that most $(68.33 \%)$ of the children were highly involved in rice cultivation, $30 \%$ were moderately involved and few (1.67\%) were not involved in rice production in the study area. The findings therefore, imply that majority of the children are involved in rice cultivation in the study area. This finding collaborates with a report that vast majority of working children are not toiling in factories and sweatshops or working as domestics or street vendors in urban areas; they are working from sunup to sundown planting and harvesting crops, spraying pesticides, and tending livestock on rural farms and plantations [25].

\section{(i) Working for}

The result in the Table further reported that majority $(68.33 \%)$ of the children worked for their parents in the rice fields whereas $31.67 \%$ of them worked as hired labourers. This revealed that children assist their parent significantly in providing manpower could be due to low income of the parents to hire labourers for farm works. This finding was in line with a report that many parents depend on their children for farm labour because their source of income could not be sufficiently enough to meet their family demands and that of farm labour [26].

\section{(ii) Children Working Hours Per Child Per Day}

Findings in the Table further revealed that majorities $(84.16 \%)$ of the children worked in the rice field for 4-7 hours/day, $15 \%$ of them worked for 1-3 hours/day and few $(0.8 \%)$ of the children worked for more than 8 hours/day. The findings further shows a mean working hours of 4.53 hours among the children. These findings indicated that children spentalmost two-third of their times per day working in the rice fields. The rule on children working in farmlands states that at age 10 and 11, local children may be engaged in harvesting short-season crops outside school hours for not more than 8 hours per week if their employers have obtained special waivers from the Secretary of Labour [27].

\section{(iii) Working Days/Week}

Child labour provisions under the Fair Labour Standards Act (FLSA) and related regulations, generally prohibit employers from hiring minors younger than age 14 and agricultural employers may hire minors younger than 14 , but only under certain conditions (the agreement of their parents and the prevailing laws of the land). As shown in Table 3, 88.33\% of the children worked for 4-5 days/week, and $5.83 \%$ of the children worked for 1-3 days/week. Similarly, the findings indicated a mean working days of the children/week as 4.55 days/week. This finding indicated that most of the days meant for schooling by the children were used for farm works and this could by the reason why most of the children in the study area had low educational attainment.

\subsection{Perceived Effects of Child Laboring Rice Production}

The involvement of children in farm works was found to have both negative and positive effects on the children, their parents and the society at large. Most of the effects of child engagement in farm works have to do with the future of the children, their health and the benefits derived by both the parents and the employers of the children in rice cultivation in the study area. Based on the above premise, the under listed perceived effects were studied discussed: 
Table 3. Distribution of children based on their involvement and benefits derived from rice cultivation $(n=120$.

\begin{tabular}{|c|c|c|c|c|}
\hline Variable & Frequency & Percentage & Mean & Standard Deviation \\
\hline \multicolumn{5}{|c|}{ Involvement in rice cultivation } \\
\hline Yes & 120 & 100 & & \\
\hline No & 0 & 0.0 & & \\
\hline \multicolumn{5}{|l|}{ Mode of involvement } \\
\hline scarecrows in the rice field & 12 & 10.0 & & \\
\hline Transplanting & 61 & 50.83 & & \\
\hline Weeding & 29 & 24.16 & & \\
\hline Fertilizer application & 5 & 4.16 & & \\
\hline Harvesting/threshing & 12 & 10.0 & & \\
\hline Transportation & 1 & 0.80 & & \\
\hline \multicolumn{5}{|l|}{ Level of involvement } \\
\hline highly involved & 82 & 68.33 & & \\
\hline moderately involved & 36 & 30.0 & & \\
\hline not involved & 2 & 1.67 & & \\
\hline \multicolumn{5}{|l|}{ Working for } \\
\hline Parent & 82 & 68.33 & & \\
\hline Self & 0 & 0.0 & & \\
\hline Hired Labour & 38 & 31.67 & & \\
\hline Community & 0 & 0.0 & & \\
\hline \multicolumn{5}{|l|}{ Working hours/day } \\
\hline 1 to 3 & 18 & 15.0 & & \\
\hline 4 to 7 & 101 & 84.16 & $4.53 \mathrm{hrs}$ & 1.04 \\
\hline 8 and above & 1 & 0.80 & & \\
\hline \multicolumn{5}{|l|}{ Working days/week } \\
\hline $1-3$ & 7 & 5.83 & & \\
\hline $4-5$ & 106 & 88.33 & 4.55days & 0.69 \\
\hline 6 days and above & 7 & 5.83 & & \\
\hline Source: Field survey, 2018 & & & & \\
\hline
\end{tabular}

\subsubsection{Children Sustain Injuries During Rice Cultivation}

The result in Table 4 shows that most $(65.8 \%)$ of the children strongly agreed that they got injured/hurt while working in the rice farms, $31.8 \%$ agreed, $1.7 \%$ of them disagreed with the statement while few $(0.8 \%)$ of the children slightly agree. These findings imply that majority of the children engaged in rice cultivation got hurt and sustain certain degree of injuries through the use of local farming tools and in most cases not medically well treated, which could subsequently lead to prolong injury that could lead to permanent deformity. Tasks of farming by children present many hazards such as: exposure to sharp tools (machetes) and dangerous machinery (tractors), risk of snakebites and injuries from other animals, exposure to extreme environmental conditions, and exposure to agro-chemicals including inorganic fertilizers and pesticides [14].

\subsubsection{Rice Cultivation Deprives Children of Their Educational Pursuance}

Results in the Table further reported that majority (71.7\%) of the children were of the agreement that engaging them in rice cultivation deprives them of their education pursuance and $15.9 \%$ of the children disagreed that engaging them in rice cultivation deprive them of their struggle to acquire educational statuses. This finding is in line with [14] reported that participating in some farm activities can give children an opportunity to develop skills and a sense of belonging to the community but it becomes a problem when the farm tasks interfere with schooling of the children and are hazardous in nature. As further reported that about seventy percent of child labourers (more than 150 million girls and boys) under the age of 18 years are agricultural workers. They are harshly exploited, toiling in poor to appalling conditions; performing dangerous jobs with little or no pay, and are deprived of an education [25].

\subsubsection{Rice Cultivation Exposes Children to Diseases}

The findings in Table 4 also show that most (64.2\%) of the children were of the agreement that rice cultivation expose them to different kind of water bone diseases, $12.5 \%$ of them slightly agree whereas $5.8 \%$ of the children disagreed that they got exposed to diseases due to involvement in rice cultivation in the study area. Findings of the study imply that almost all the children were of the view that involving them in rice cultivation exposed them to different illnesses that are associated with water borne diseases. A research findings revealed that rice cultivation is associated with exposure to numerous preventable disease agents that may cause musculo-skeletal disorders, skin diseases, respiratory diseases, zoonoses, parasitic diseases and cancer [28].

\subsubsection{Rice Cultivation Exposes Children to Hunger and Starvation}

As indicated in the Table, more than half $(57.5 \%)$ of the children agreed with fact that their involvement in rice cultivation exposed them to hunger and starvation, $30.8 \%$ slightly agree whereas $4.17 \%$ of the children were of the 
view that engaging them in rice cultivation did not exposed them to hunger and starvation. The assertion of the children that they were exposed to hunger and starvation could be true due to the fact that in the study area, it's not all parents that feed their children while working in the rice fields due to poverty while majority of the employers will bargain with children for the work to be done without feeding.

\subsubsection{Rice Cultivation Exposes Children to Social Vices and Indecent Behaviours}

Similarly, the findings in Table 4 also reveal that $25.8 \%$ of the children were of the agreement that rice cultivation exposes them to some social vices and indecent behaviours while at least $12.5 \%$ disagreed with the statement. This finding therefore, indicated that the absence of the children's parents in farm field give them an opportunity to perpetuate on any indecent behaviour that could lead to social vices. Based on [24], the origin of the problem of child labour can be traced to some difficult social vices, illiteracy, poverty, inequality, failure of social welfare schemes, and population explosion.

\subsubsection{Long Hours Away from Home Expose Children to Unwholesome Associations and Gangs}

Table 4 further depicts that $54.2 \%$ of the children remained undecided on the statement that long hours away from home expose them to unwholesome associations and gangs, $26.7 \%$ of them were of the agreement that long time away from parents could result unwholesome associations and only few $(11.6 \%)$ of the children disagreed with the fact that engaging them in rice cultivation for longer hours of the day contribute to unwholesome associations and formation of gangs.

\subsubsection{Children are Exposed to Tedious Activities}

Table 4 revealed that most $(58.3 \%)$ of the children were of strong view that they were exposed to tedious work, $38.3 \%$ agreed while few $(3.3 \%)$ of the children remained undecided on the statement. The findings imply that rice cultivation is a labour intensive work and as such most of the children engaged in to the activity were of the view that rice cultivation is laborious and tedious to their making, and hence, it affects their health and its repercussion manifested in their schooling. Based on this finding, engaging children in rice cultivation could be considered as child labour. Findings of a similar study indicated that light duties that do harm to the child and which interfere with compulsory schooling and damages health and personal development of children are considered as child labour [14].

Table 4. Perception of the children based on problems associated with engagement in rice cultivation $(n=120)$.

\begin{tabular}{|c|c|c|c|c|c|c|c|c|}
\hline S/No. & Attitudinal statement & SA & $\mathbf{A}$ & $\mathbf{S}$ & D & D & Mean & Ranking \\
\hline 1. & Children sustain injuries during rice cultivation & $79(65.8)$ & $41(31.8)$ & $0(0.0)$ & $0(0.0)$ & $0(0.0)$ & 1.34 & $6^{\text {th }}$ \\
\hline 2. & $\begin{array}{l}\text { Rice cultivation deprives children of their educational } \\
\text { pursuance }\end{array}$ & $2(1.67)$ & $86(71.7)$ & $13(10.83)$ & $17(15.9)$ & $2(1.67)$ & 3.58 & $1^{\text {st }}$ \\
\hline 3. & Rice cultivation exposes children to diseases & $21(17.5)$ & $77(64.17)$ & $15(12.5)$ & $7(5.83)$ & $0(0.0)$ & 2.07 & $4^{\text {th }}$ \\
\hline 5. & Rice cultivation exposes children to hunger and starvation & $1(0.83)$ & $69(57.5)$ & $37(30.83)$ & $8(6.67)$ & $5(4.17)$ & 3.58 & $1^{\text {st }}$ \\
\hline 6. & $\begin{array}{l}\text { Rice cultivation exposes children to social vices and indecent } \\
\text { behaviours }\end{array}$ & $4(3.33)$ & $27(225)$ & $74(61.67)$ & $13(10.83)$ & $2(1.67)$ & 2.85 & $2^{\text {nd }}$ \\
\hline 7. & $\begin{array}{l}\text { Long hours away from home expose children to unwholesome } \\
\text { associations and gangs }\end{array}$ & $9(7.5)$ & $32(26.67)$ & $65(54.17)$ & $13(10.83)$ & $1(0.83)$ & 2.71 & $3^{\text {rd }}$ \\
\hline 8. & Children are exposed to tedious activities & $70(58.33)$ & $46(38.33)$ & $4(3.33)$ & $0(0.0)$ & $0(0.0)$ & 1.45 & $5^{\text {th }}$ \\
\hline
\end{tabular}

Source: Field survey, 2018; SA (Strongly Agree); A (Agree); S (Slightly agree); D (Disagree); SD (Strongly disagree); Percentages in parenthesis ().

\subsection{Ranking of Children Perception on Rice Cultivation}

Ranking of response of children perception on their engagement in to rice cultivation was done based on the mean response on the perceived attitudinal statements. Findings in Table 4 revealed that depriving children from educational pursue and exposure to hunger and starvation were ranked first implying that children engaged in rice cultivation by either their parents or the employer of their labour were denied their total participation in pursuance of education and at the same time exposed them to hunger and starvation. Exposure of children to social vices, indecent behaviours and unwholesome associations and formation of gangs due to long hours away from home/parents were ranked second and third respectively.

\subsubsection{Perceived Rice Yield Due to Children Involvement}

In comparing the yield of the parents and employers of the children in rice cultivation, parents and employers were asked to provide information on yield of rice as a result of children involvement and without their involvement in the cultivation. Results obtained in Table 5 revealed that $3(2.5 \%)$ of the farmers obtained more than 61 bags without children involvement compared with $45(37.5 \%)$ of the farmers that more than 61 bags of rice when children were involved. Findings in the Table further posit that $4(3.33 \%)$ of farmers got a yield of 46-60 bags of rice without children involvement compared to $37(30.83 \%)$ of the farmers that obtained a yield of 46-60 bags of rice with involvement of children. Also, the mean yield without children involvement was about 17 bags more less than 31 bags when children were involved in to rice cultivation. As could be deduced from the findings of the study, involving children in rice cultivation in the study attracts more yields which consequently could affect children enrolment in to school and other skill acquisition efforts. 
Table 5. Yield of parents/employers with and without children $(n=120)$.

\begin{tabular}{|c|c|c|c|c|c|c|}
\hline Yield & Without & Children & & Yield & With & Children \\
\hline Variables & Frequency & Percentage & Mean & Frequency & Percentage & Mean \\
\hline \multicolumn{7}{|l|}{ Yield (bags) } \\
\hline$<1$ bag & 15 & 12.5 & & 2 & 1.67 & \\
\hline $1-15$ & 53 & 44.17 & & 5 & 4.17 & \\
\hline $16-30$ & 38 & 31.67 & 16.84 & 12 & 10.0 & 31.24 \\
\hline $31-45$ & 7 & 5.83 & & 19 & 15.83 & \\
\hline $46-60$ & 4 & 3.33 & & 37 & 30.83 & \\
\hline 61 bags and above & 3 & 2.5 & & 45 & 37.5 & \\
\hline
\end{tabular}

Source: Field survey, 2018

\subsubsection{Relationship between Children Involvement and Yield of Rice}

Multiple regression analysis result in Table 6 revealed a significant relationship $(\mathrm{P}<0.05)$ between involvement of children in rice cultivation and yield obtained by parents and or the employers of the children in the rice fields. The findings of the study imply that those parents and other famers that maximally employ the labour of children were able to realize appreciable yield in the study area.

Table 6. Relationship between children involvement and rice yield obtained.

\begin{tabular}{|c|c|c|c|c|c|}
\hline \multirow{2}{*}{ Variables } & \multirow{2}{*}{$\begin{array}{l}\text { Children involvement } \\
\text { Unstandardized Coefficient }\end{array}$} & \multirow{2}{*}{$\begin{array}{l}\text { In } \\
\text { SE }\end{array}$} & \multicolumn{3}{|l|}{ Cultivation } \\
\hline & & & Standardized Coefficient & t-ratio & P-value \\
\hline Constant & & 0.107 & 0.811 & 7.595 & $.000 * * *$ \\
\hline Yield of rice without children & -0.017 & 0.014 & 0.113 & 1.215 & 0.278 \\
\hline Yield of rice with children & 0.022 & 0.021 & 0.099 & 1.064 & $0.007 *$ \\
\hline \multicolumn{6}{|l|}{$\mathrm{R}=0.162$} \\
\hline \multicolumn{6}{|l|}{$\mathrm{R}^{2}=0.026$} \\
\hline$\Delta \mathrm{R}^{2}=0.26$ & & & & & \\
\hline
\end{tabular}

SE - Standard error; P*** - Significant at 0.01\%; P* -Significant at $0.05 \%$

\section{Conclusion}

Based on the objectives that guided this study, it is concluded that all the children involved in rice production in the study area were between the ages of 4-17 years, majority with Qur'anic education only and mostly from a household size of about 12 family members. The study also concluded that most of the children were actively involved in rice cultivation with majority perceiving that they were denied of active participation in schooling and that the work was tedious and worked under hunger and starvation. The findings of the study also revealed that all the parents and other farmers that involved children in their rice cultivation got appreciable yield.

\section{Recommendations}

Based on the findings of this study, the following recommendations deemed necessary:

a. There should be restriction to the age at which children are actively involved in rice cultivation in the study area

b. Time of engaging children in rice cultivation and their schooling hours should be balanced so as to allow children to participate in both.

c. In order to reduce drudgery associated with rice cultivation, modern farming tools that could be easily operated by the children are recommended.

d. It's recommended that government, nongovernmental organizations and well-to-do individuals should come up with better programmes that motivate children to schooling and skills acquisition better than that of rice cultivation involvement.

e. More poverty alleviation programmes are recommended because it was ascertained that poverty was instrumental to child labour in the study area.

\section{References}

[1] Opara, U. N (2008). Agricultural Information Sources Used by Farmers in Imo State, Nigeria. Retrieved from https://www.researchgate.net/publication/240713976_Agricult ural_Information_Sources_Used_by_Farmers_in_Imo_State_ Nigeria on $22 \mathrm{nd}$ October, $\overline{2} 020$ at $2: \overline{2} 3 \mathrm{Pm}$.

[2] Food and Agriculture Organization - FAO (2015). Child labour in Agriculture in Lebanon. A Guide to Practitioners.

[3] Regine, A. (2016). Governing agro biodiversity: Plant genetics and developing countries. Rutledge, 20.

[4] Abubakar, B. Z., Ango, A. K. and Buhari, U. (2009). The Roles of Mass Media in Disseminating Agricultural Information to Farmers in BirninKebbi Local Government Area of Kebbi State: A Case Study of State Fadama II Development Project. Journal of Agricultural Extension, 13 (2), 42 .

[5] Premium Times Newspaper (2017). Rice Production in Nigeria. Retrieved from https://www.premiumtimesng.com/agriculture/agricnews/240287-rice-production-nigeria-hits-15-million-tonnesofficial.html on 19th October, 2020 at 2:54Pm. 
[6] ILO-IPEC (2004). Hazardous Child Labour in Agriculture: An Overview. ILO-IPEC.

Geneva. Safety and Health Fact Sheet, 2004. Available atwww.ilo.org/ipec.

[7] Odebode, S. O. (2000). Youth Participation in Rural Development Oyo State Department of Agricultural Extension and Rural Development. University of Ibadan, Ibadan, Nigeria

[8] Akinbile L. A. and Otitolaya, O. O. (2008). Assessment of Extension Agents' Knowledge in the Use of Communication Channels for Agricultural Information Dissemination in Ogun State, Nigeria. Journal of Agricultural and Food Information, 9 (4), 341-353.

[9] Barrientos, S., Asenso-Okyere, K., Assuming-Brempong, S. and Sarpong, D. B. (2015). Mapping Sustainable Production in Ghanian Cocoa. Retrieved from https://www.researchgate.net/publication/281207478_Mappin g Sustainable Production in Ghanaian Cocoa on 22nd October, 2020 at 2:07Pm.

[10] Mull, L. D., Kirkhorn, S. R. (2005). Child Labour in Ghana Cocoa Production: Focus upon Agricultural Tasks, Ergonomic Exposures and Associated Injuries and Illnesses. Public Health Reports, 120 (6), 649-655.

[11] International Labour Organization- ILO (2008). World of Work Report. Retrieved from https://www.ilo.org/wcmsp5/groups/public/---dgreports/--dcomm/---publ/documents/publication/wcms 100354.pdf on 19th October, 2020 at 3:01Pm.

[12] International Labour Organization- ILO (2006). The End of Child Labour: Within Reach. Global Report under Follow-up to the ILO Declaration on Fundamental Principles and Rights at Work, 72, 885-897.

[13] International Labour Organization- ILO (2010). Accelerating Action against Child Labour. Global Report under the Followup to the ILO Declaration on Fundamental Principles and Rights at Work. International Labour Conference, 99th Session, 2010. Geneva, ILO, 98.

[14] International Labour Organization-ILO (2019). Advancing Social Justice, Promoting Decent Work. Accessed from http://www.ilo.org/ipec/areas/Agriculture/WCMS_172416/lan g--en/index.htm on 19th March, 2019 at 09:48Am.

[15] Mendelievich, E. (1979). Children at Work. International Labour Office, Geneva, 55.

[16] Akarro, R. R. J. and Mtweve, N. A. (2011). Poverty and its Association with Child Labour in Njombe District in Tanzania: The Case of Igima Ward. Current Research Journal of Social Sciences, 3 (3), 199-206.
[17] Singh, S., Kushwaha, B. P., Nag, S. K., Mishra, A. K., Bhattacharya, S., Gupta, P. K., Singh, A. (2011). In vitro Methane Emission from Indian Dry Roughages in Relation to Chemical Composition. Current Science, 101 (1), 57-65.

[18] Uganda Child Labour Report (2016). Significant Advancement. Retrieved from https://www.justice.gov/eoir/page/file/1012216/download on 19th October, 20202 at 3:43Pm.

[19] International Labor Organization- ILO (2012). Marking progress against child labour. Global estimate and trends 2000-2012. Governance and Tripartism Department. 5, 7-9.

[20] Glory E. E. and Nsikak-AbasiA. E. (2013). Child Labor in Agriculture among Poor Rural Households: Some Facts and Issues. European Journal of Physical and Agricultural Sciences, 1 (1), 3.

[21] Usman, T., Ango, A. K., Barau, A. A. (2013). Evaluation of Adoption of Improved Rice Varieties Among Small-Scale Farmers: A case of Goronyo Local Government Area of Sokoto State, North-Western Nigeria. Journal of Agriculture Innovations and Research, 2 (3), 2319-1473.

[22] Cocoa Initiative (2020). The Effects of Income Changes on Child Labour: A Review of Evidence from Smallholder Agriculture. Retrieved from https://cocoainitiative.org/wpcontent/uploads/2020/04/ICI Lit Review Income ChildLabo ur_15Apr2020.pdf on 19th October, 2020 at 4:21Pm.

[23] Adnan, S. (2019). Important reasons of Child Labor: An analysis to save poor children. Accessed from http://www.extremology.com/2013/02/Important-reasons-ofchild-labor-with-analysis.html on $05 / 03 / 2019$ at $2.55 \mathrm{Pm}$.

[24] Child Labour (2011). Government Point of View. Retrieved from https://osamah-childlabour.blogspot.com/ on 04/04/2019 at 09:57 Am.

[25] Hurst, P. (2007). Health and child labor in agriculture. Food and Nutrition Bulletin, 28 (2), 364-371. Retrieved from https://journals.sagepub.com/doi/pdf/10.1177/1564826507028 2S216 on 05/08/2019 at 03:02Pm.

[26] Patrinos, H. and Psacharapolous, G. (1997). "Family Size, Schooling and Child Labour in Peri: An Empirical Analysis. Journal of Population Economics, 10, 387-405.

[27] Fair Labour Standards Act - FLSA (2018). Child Labour Facts Sheet/NCFH. Accessed from http://www.ncfh.org/uploads/3/8/6/8/38685499/fschild labor.pdf on 14/03/2019 at 10:42 Am.

[28] Joshi, M. D. (2012). Rice Field Work and the Occupational Hazards. Occupational Hazards, 4: 111-114. 